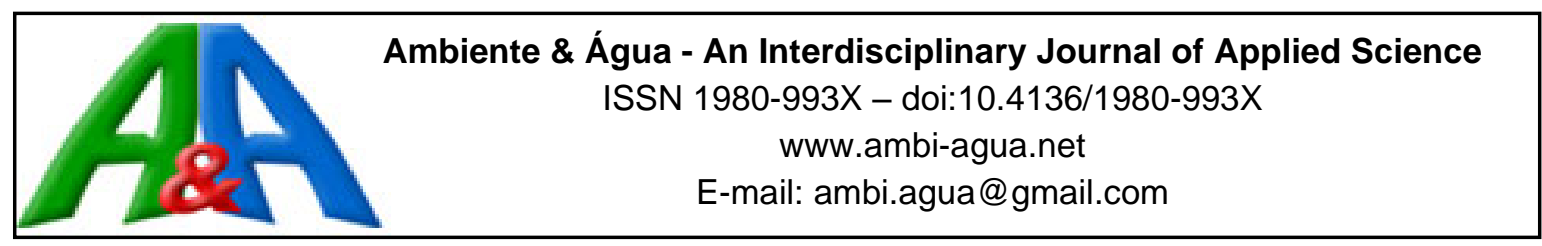

\title{
Impacts of dam construction on the macroinvertebrate community in the Poxin-Açú, in a tropical region
}

\author{
ARTICLES doi:10.4136/ambi-agua.2704
}

Received: 01 Feb. 2021; Accepted: 04 Oct. 2021

\author{
Anderson Nascimento do Vasco ${ }^{1 *}$; ; Amanda Vaz de Souza Oliveira1 ${ }^{1}$; \\ Geovane Alves Feitosa ${ }^{1}$; ; Talita Guimarães Araújo-Piovezan ${ }^{2}$; \\ Agripino Emanuel Oliveira Alves ${ }^{1}$; ; José Oliveira Dantas ${ }^{2}$ ic \\ ${ }^{1}$ Departamento de Agroecologia. Instituto Federal de Educação, Ciência e Tecnologia de Sergipe (IFS), \\ Rodovia BR 101, Km 96, s/n, CEP: 49100-000, São Cristóvão, SE, Brazil. \\ E-mail:vazdesouza.o@gmail.com,geovane_feitosa@hotmail.com, aeoalves@gmail.com \\ ${ }^{2}$ Departamento de Biologia. Instituto Federal de Educação, Ciência e Tecnologia de Sergipe (IFS), \\ Rodovia BR 101, Km 96, s/n, CEP: 49100-000, São Cristóvão, SE, Brazil. \\ E-mail: talit_a@hotmail.com, josedantas336@gmail.com \\ *Corresponding author. E-mail: anderson.vasco@ifs.edu.br
}

\begin{abstract}
River regularization plays an important role in socio economic development. However, it also modifies the natural flow system of the river and its biotic and abiotic characteristics, causing significant impacts on rivers. To evaluate the impacts on the macroinvertebrate community caused by dam construction on the Poxim-Açú River, metrics of composition and community structure of the macroinvertebrates were analyzed, as well as ecological and biological traits of the region. Macroinvertebrates were collected at three sites located downstream the dam, before (2013) and after (2015) dam construction. The water quality was classified as "good" to "excellent" according to the biotics indices. The alterations of the flow regime of the river after the dam construction influenced the macroinvertebrate communities, modifying their diversity, equitability, richness, and the number of individuals.
\end{abstract}

Keywords: bioindicators, dam impacts, environmental monitoring.

\section{Impactos da construção de barragem na comunidade de macroinvertebrados no rio Poxim-Açu numa região tropical}

\begin{abstract}
A regularização de rios tem papel fundamental para o desenvolvimento socioeconômico de uma região, porém resulta em alterações em larga escala no regime de fluxo natural e modifica potencialmente uma ampla gama de fatores abióticos e bióticos, sendo considerado um dos impactos ambientais mais significativo nos rios em todo o mundo. Este estudo tem como objetivo avaliar os impactos na comunidade de macroinvertebrados ocasionado pela construção de uma barragem para armazenamento de água no rio Poxím-Açú, bem como características biológicas e ecológicas locais. Foram realizadas coletas de macroinvertebrados em três pontos a jusante da barragem em dois períodos distintos: anterior a construção da barragem (2013) e posterior a barragem (2015). A qualidade da água foi classificada como de boa e excelente qualidade, respectivamente, por meio dos índices bióticos. Alterações nas


comunidades de macroinvertebrados foram observadas devido as modificações do regime de vazão, como resultado da construção da barragem, que influenciou na composição e estrutura das comunidades de macroinvertebrados e se reflete nas mudanças na diversidade, equitabilidade, riqueza e número de indivíduos no período anterior e posterior a barragem.

Palavras-chave: bioindicadores, impactos de barragens, monitoramento ambiental.

\section{INTRODUCTION}

In the last two decades, it has become evident that several anthropic activities in aquatic environments are connected with the imbalance of biological communities (Camargo et al., 2019). Among them, the damming of the rivers potentially modifies various biotic and abiotic conditions in the lotic ecosystems, being considered one of the most significant anthropic impacts on rivers worldwide (Tonkin et al., 2018; Krajenbrink et al., 2019).

Dam construction could discontinue the connections between habitats upstream and downstream of the river (Dynesius and Nilsson, 1994), altering physical, chemical, and biological components of the lotic and lentic environments (Brooks et al., 2018). Generally, physical impacts are related to the flow regime of the river, water temperature, water transparency, and reduction of sediments downstream of the dam (White et al., 2017; Wu et al., 2019). The most common chemical impacts are the reduction of dissolved oxygen in water and the reduction of phosphorus and nitrogen nutrients. The biological impacts could be related to the avoidance of migratory movement, reduction of the reproduction rate, reduction of the physiological efficiency due to the absence of oxygen, shifts in the diet pattern of the species, increase in the abundance of the most dominant and tolerant species, facilitation for the colonization process and establishment of exotic species.

To monitor environmental quality, aquatic macroinvertebrates are generally used, since several groups of these animals are highly sensitive to anthropogenic changes (Baptista, 2008). Macroinvertebrates are useful indicators, due to their specificity with certain types of impacts, as many species are demonstrably sensitive to one type of pollutant, or more tolerant to others (Pompeu et al., 2005). Most studies around the world discuss the effect of dam construction on the ecological structure of the aquatic communities (Wang et al., 2019).

However, there is a lack of this information on tropical regions, especially related to the Brazilian Northeast portion; direct comparison between macroinvertebrate communities in the periods before and after the construction of the dam has been impossible due to the absence of monitoring data (Maynard and Lane, 2012). Most studies have compared sites downstream of dams with control sites that do not represent natural conditions downstream (Holt et al., 2015). On the other hand, this work compares macroinvertebrate occurrence data downstream of the reservoir before and after the damming of the river.

The main objective was to identify differences in the structure and composition of the macroinvertebrate community related to the construction of the Jaime Umbelino de Souza Dam on the Poxim-Açú River.

\section{MATERIAL AND METHODS}

\subsection{Study site}

The Poxim-Açu River is the main tributary of the hydrological basin of the Sergipe River $\left(10^{\circ} 55^{\prime} \mathrm{S}, 37^{\circ} 12^{\prime} \mathrm{W}\right)$. The micro-basin has an area of $128,08 \mathrm{~km}^{2}$, with a main river channel of $26.7 \mathrm{~km}$ and an altitude range of $478 \mathrm{~m}$ (Figure 1). It is possible to observe different land cover and land uses over the Poxim-Açú River course, including livestock (50.30\%), seasonal forest $(36.56 \%)$, cultivated agricultural areas, exposed soil $(6.97 \%)$, riparian forest $(3.11 \%)$, and degraded areas (2.31\%) (Rocha et al., 2014). 

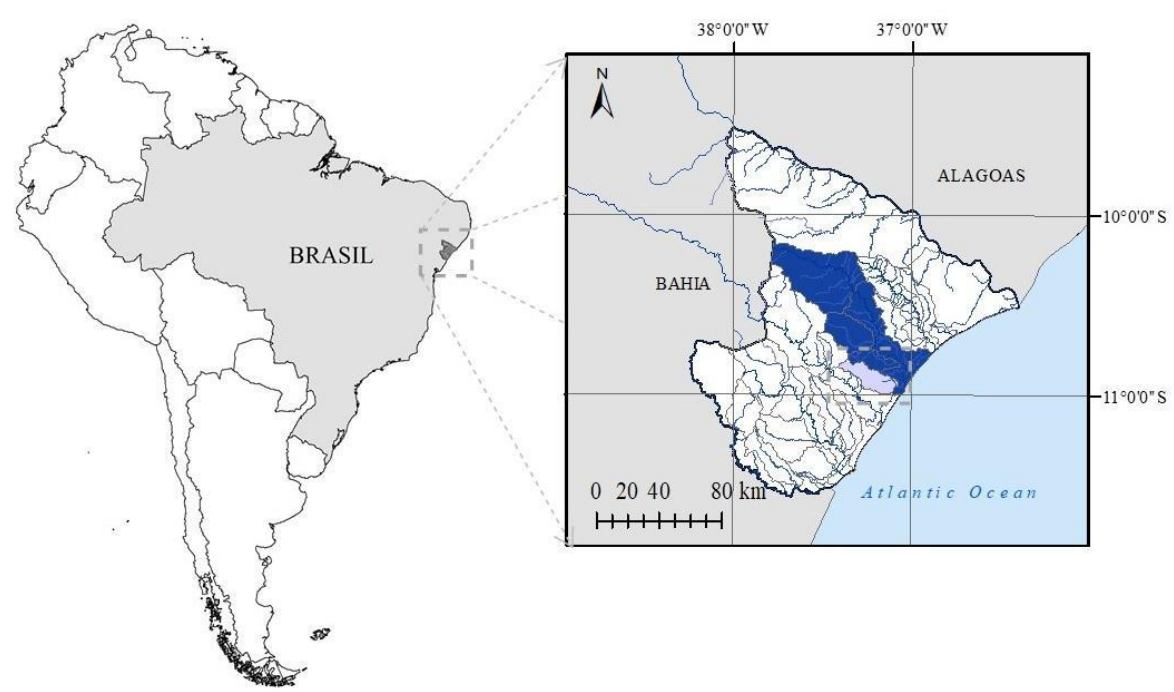

Figure 1. Representation of the Poxim-Açu River Basin, showing the location of the data collection downstream from the dam.

The region has a humid tropical climate, with a dry season from August to March and a rainy season from April to July, with an annual average precipitation varying from 1,600 to $1,900 \mathrm{~mm}$ and annual average temperature of $27^{\circ} \mathrm{C}$, varying from 23 to $31^{\circ} \mathrm{C}$. The Jaime Umbelino de Souza Dam was built over the Poxim-Açu River in Sergipe, and it was inaugurated in 2013 for the purpose of water storage. The dam is located at Timbo's village, Municipality of São Cristóvão, Sergipe department. The dam's reservoir has an area of $5.2 \mathrm{~km}^{2}$ and a water storage capacity of 32 million cubic meters (Rocha et al., 2014).

\subsection{Insects Collection}

Collection of macroinvertebrates and abiotic data was carried out monthly in three places on the river in the period before (January to August 2013) and after (August 2014 to July 2015) dam construction. The characteristics of the sampling points downstream of the dam with average distances of $300 \mathrm{~m}$ were: Point $1\left(10^{\circ} 55^{\prime} 183^{\prime \prime} \mathrm{S}, 37^{\circ} 11^{\prime} 264^{\prime \prime} \mathrm{W}\right.$, altitude $\left.38 \mathrm{~m}\right)$ presenting substrate with pebbles and gravel, with less than $5 \%$ of the disposal of the sludge at the bottom of the river and a lack of it at the backwaters. More than $50 \%$ of the river bottom has diversified habitats with the presence of submerged trunks and gravel. There are changes in the river channel with the opening of ditches, felled trees, related to the channeling of the dam's mains, dragging sediment, and contributing to the siltation of the river.

Point $2\left(10^{\circ} 55^{\prime} 188^{\prime \prime} \mathrm{S}, 37^{\circ} 11^{\prime} 180^{\prime \prime} \mathrm{W}\right.$, altitude $\left.30 \mathrm{~m}\right)$ - substrate mainly composed of gravel and some pebbles. Ten to $30 \%$ of the habitats are stable, but substrates are frequently modified by anthropic actions that increase gravel, sand, and sludge disposal. In addition, 5 to $30 \%$ of the river bottom is affected by these actions, causing some disposal at the river's backwaters.

Point $3\left(10^{\circ} 55,195^{\prime}\right.$ and $S 37^{\circ} 11,119^{\prime} \mathrm{W}$ altitude $\left.27 \mathrm{~m}\right)$ - a substrate formed by gravel, sand, and some pebbles is predominant. The type of bottom is considered medium, where there are 10 to $30 \%$ of stable habitats; substrate frequently modified mainly by increasing gravel, sand or mud; 5 to $30 \%$ of the affected amount; gentle deposition in the backwaters.

The insects were collected using a " $D$ " net with a $0.05 \mathrm{~mm}$ mesh opening over marginal vegetation, bottom sediments, and water column. The entomological material was sorted in the field with the help of tweezers, plastic trays and placed in bottles with $70 \%$ alcohol. The material was taken to the Entomology Laboratory of the Federal Institute of Sergipe, Campus São Cristóvão, and identified at the family level with the aid of a stereoscopic microscope and specialized literature (Magnai et al., 2010). 


\subsection{Biotic Index and Data Analysis}

Initially, all data were evaluated for normality using the Shapiro-Wilk test, aiming to determine the application of parametric or nonparametric analyses. To assess the diversity of the three sampling points, the total richness $(\mathrm{S})$, Shannon-Wiener Log Base 10 index $\left(\mathrm{H}^{\prime}\right)$, Pielou equitability $\left(\mathrm{J}^{\prime}\right)$, and the dominance of the main taxon $(\mathrm{k})$ were used. The latter is defined by the percentage of occurrence of the most abundant taxon with the others. To determine these indices, the PAST Software was used (Hammer, 2017).

To assess water quality, the Biological Monitoring Working Party (BMWP) index was applied. This index is a scale from 1 to 10 , along which the sensitivity of various insect and other macroinvertebrate families are scored, with the highest scores assigned to species most sensitive to organic pollution. To interpret the total scores of the BMWP index, the table of values proposed by Alba-Tercedor (1996) was used, correlating these values to the water quality in the three sampling points shown respectively (Table 1).

Table 1. BMWP index scores interpretation according to Alba-Tercedor (1996).

\begin{tabular}{ccc}
\hline Class & BMWP & Water quality \\
\hline 1 & $>150$ & Excellent \\
2 & $101-120$ & Good (Acceptable) \\
3 & $36-60$ & Medium (Doubtful) \\
4 & $16-35$ & Bad (Critical) \\
5 & $<15$ & Very Bad (Very Critical) \\
\hline
\end{tabular}

Another index used was the EPT (proportion of Ephemeroptera, Plecoptera, and Trichoptera), where all organisms of the orders Ephemeroptera, Plecoptera, and Trichoptera present in the sample are considered, and the relative abundance of these orders concerning the total number of organisms in the sample is calculated, the result is obtained through the Equation 1:

$$
E P T \%=\frac{n^{\circ} \text { Indivíduos (Ephemeroptera }+ \text { Plecoptera }+ \text { Trichoptera) }}{n^{\circ} \text { total de indivíduos }} \times 100
$$

The result of this index is compared with the values that Gonçalves (2011) proposed (Table 2) below.

Table 2. EPT index scores interpretation, according to Gonçalves (2011).

\begin{tabular}{cl}
\hline EPT $(\%)$ & Water quality \\
\hline $75 \%-100 \%$ & Very Good \\
$50 \%-74 \%$ & Good \\
$25 \%-49 \%$ & Average \\
$0 \%-24 \%$ & Bad \\
\hline
\end{tabular}

\section{RESULTS AND DISCUSSION}

In this study 12,362 individuals were collected, distributed into 32 families. Among these, 12,356 belong to Class Insecta, and the others to Class Crustacea (04) and Phylum Annelida (02). The number of individuals of each taxon and each sampling point is presented in Table 3 .

Rev. Ambient. Água vol. 16 n. 6, e2704 - Taubaté 2021 
Table 3. Macroinvertebrates were collected at three points of the Poxim-Açú River before (BD) and after (AD) the construction of the Jaime Umbelino de Souza Dam.

\begin{tabular}{|c|c|c|c|c|c|c|c|c|c|c|}
\hline \multirow{2}{*}{ Orders } & \multirow{2}{*}{ Families } & \multirow{2}{*}{$\frac{\text { Score }}{\text { BMWP* }}$} & \multicolumn{4}{|c|}{$\begin{array}{l}\text { Before the Dam (BD) } \\
\text { (2013) }\end{array}$} & \multicolumn{4}{|c|}{$\begin{array}{l}\text { After the Dam (AD) } \\
\qquad(2015)\end{array}$} \\
\hline & & & $\mathrm{P} 1$ & $\mathrm{P} 2$ & P3 & Total & $\mathrm{P} 1$ & $\mathrm{P} 2$ & P3 & Total \\
\hline \multirow{7}{*}{ Hemiptera } & Veliidae & 3 & 160 & 207 & 556 & 923 & 287 & 155 & 303 & 745 \\
\hline & Belostomatidae & 3 & 7 & 1 & 3 & 11 & 22 & 20 & 30 & 72 \\
\hline & Notonectidae & 3 & 0 & 1 & 0 & 1 & 5 & 10 & 7 & 22 \\
\hline & Gerridae & 3 & 27 & 8 & 35 & 70 & 42 & 24 & 41 & 107 \\
\hline & Nepidae & 3 & 0 & 2 & 0 & 2 & 8 & 1 & 5 & 14 \\
\hline & Naucoridae & 3 & 0 & 0 & 0 & 0 & 1 & 1 & 5 & 7 \\
\hline & Mesoveliidae & 3 & 0 & 0 & 0 & 0 & 0 & 0 & 5 & 5 \\
\hline \multirow{4}{*}{ Ephemeroptera } & Leptophlebiidae & 10 & 131 & 198 & 60 & 389 & 417 & 371 & 236 & 1024 \\
\hline & Leptohyphidae & 6 & 654 & 475 & 678 & 1807 & 150 & 59 & 35 & 244 \\
\hline & Baetidae & 4 & 52 & 44 & 57 & 153 & 29 & 20 & 22 & 71 \\
\hline & Caenidae & 4 & 0 & 0 & 0 & 0 & 1 & 2 & 4 & 7 \\
\hline \multirow{6}{*}{ Diptera } & Culicidae & 2 & 0 & 0 & 0 & 0 & 0 & 3 & 0 & 3 \\
\hline & Simulidae & 2 & 8 & 10 & 7 & 25 & 27 & 22 & 0 & 49 \\
\hline & Tipulidae & 4 & 1 & 1 & 1 & 3 & 4 & 6 & 3 & 13 \\
\hline & Empididae & 2 & 0 & 6 & 0 & 6 & 0 & 0 & 3 & 3 \\
\hline & Chironomidae & 2 & 224 & 82 & 36 & 342 & 27 & 47 & 29 & 103 \\
\hline & Ceratopogonidae & 2 & 0 & 0 & 0 & 0 & 0 & 1 & 0 & 1 \\
\hline \multirow{5}{*}{ Trichoptera } & Hydropsychidae & 5 & 162 & 267 & 44 & 473 & 608 & 481 & 180 & 1269 \\
\hline & Polycentropodidae & 7 & 0 & 0 & 0 & 0 & 54 & 42 & 72 & 168 \\
\hline & Philopotamidae & 8 & 0 & 0 & 0 & 0 & 402 & 592 & 227 & 1221 \\
\hline & Leptoceridae & 10 & 0 & 0 & 0 & 0 & 0 & 0 & 1 & 1 \\
\hline & Xiphocentronidae & 7 & 0 & 0 & 0 & 0 & 0 & 1 & 0 & 1 \\
\hline Megaloptera & Corydalidae & 4 & 0 & 0 & 0 & 0 & 7 & 21 & 7 & 35 \\
\hline
\end{tabular}

Continue... 


\begin{tabular}{|c|c|c|c|c|c|c|c|c|c|c|}
\hline Continued... & & & & & & & & & & \\
\hline \multirow{9}{*}{ Odonata } & Aeshnidae & 8 & 0 & 0 & 1 & 1 & 14 & 2 & 0 & 16 \\
\hline & Libellulidae & 8 & 86 & 160 & 114 & 360 & 323 & 462 & 311 & 1096 \\
\hline & Corduliidae & 8 & 0 & 0 & 0 & 0 & 7 & 0 & 7 & 14 \\
\hline & Calopterigidae & 8 & 43 & 21 & 44 & 108 & 107 & 239 & 215 & 561 \\
\hline & Dicteriadiadae & 8 & 0 & 0 & 0 & 0 & 0 & 16 & 0 & 16 \\
\hline & Megapodagrionidae & 10 & 0 & 0 & 0 & 0 & 2 & 1 & 2 & 5 \\
\hline & Perilestidae & 8 & 0 & 0 & 0 & 0 & 0 & 0 & 3 & 3 \\
\hline & Coenagrionidae & 6 & 15 & 8 & 6 & 29 & 83 & 111 & 98 & 292 \\
\hline & Gomphidae & 8 & 2 & 4 & 24 & 30 & 50 & 38 & 51 & 139 \\
\hline \multirow{5}{*}{ Coleoptera } & Gyrinidae & 3 & 0 & 0 & 0 & 0 & 68 & 92 & 75 & 235 \\
\hline & Dytiscidae & 3 & 1 & 0 & 0 & 1 & 11 & 0 & 1 & 12 \\
\hline & Crysomelidae & 3 & 0 & 0 & 0 & 0 & 0 & 1 & 0 & 1 \\
\hline & Staphilinidae & 3 & 1 & 0 & 0 & 1 & 1 & 0 & 2 & 3 \\
\hline & Elmidae & 5 & 4 & 6 & 4 & 14 & 0 & 6 & 2 & 8 \\
\hline Lepidoptera & Pyralidae & 7 & 3 & 0 & 14 & 17 & 0 & 6 & 1 & 7 \\
\hline Crustacea & Isopoda & 3 & 0 & 0 & 0 & 0 & 0 & 2 & 0 & 2 \\
\hline \multirow[t]{2}{*}{ Phylum Annelida } & Hirudinea & 1 & 0 & 0 & 0 & 0 & 1 & 0 & 0 & 1 \\
\hline & Total & - & 1581 & 1501 & 1684 & 4766 & 2758 & 2855 & 1983 & 7596 \\
\hline
\end{tabular}


Before the construction of the dam, 4,766 individuals were collected, divided mainly into five orders: Ephemeroptera (49\%), Hemiptera (21\%), Odonata (11\%), Trichoptera (10\%), and Diptera $(8 \%)$, with all the other orders representing less than $1 \%$. In the period after the construction of the dam, 7,596 individuals were collected, divided mainly into five orders: Trichoptera (35\%), Ephemeroptera (28\%), Odonata (28\%), Hemiptera (13\%), and Coleoptera (3\%), with all the other orders representing less than $2 \%$.

It is noteworthy that there was an increase in the number of Trichoptera in the period after the construction of the dam. This can be explained by the control of the river's flow, which maintained the stability of the habitats and reduced the carrying of particles and organisms (Copatti et al., 2014). This action contributes to the improvement of the BMWP biotic index due to the presence of a greater number of families (Bispo et al., 2001), but there was a reduction in the EPT index (Table 4).

Table 4. Abiotic parameters before and after the dam construction.

\begin{tabular}{|c|c|c|}
\hline \multirow{2}{*}{ Parameters } & \multicolumn{2}{|c|}{ Sampling Periods } \\
\hline & Before the dam & After the dam \\
\hline Maximum Flow Regime $\left(\mathrm{m}^{3} \mathrm{~s}^{-1}\right)$ & 6.94 & 4.71 \\
\hline Average Depth (m) & 0.34 & 0.28 \\
\hline $\mathrm{pH}$ & 7.10 & 7.70 \\
\hline Turbidity (NTU) & 43.10 & 7.68 \\
\hline Nitrate $\left(\mathrm{mg} \mathrm{L}^{-1}\right)$ & 3.02 & 0.86 \\
\hline Total Phosphorus (mg L ${ }^{-1}$ ) & 0.40 & 0.07 \\
\hline Chlorophyll $\left(\mu \mathrm{g} \mathrm{L}^{-1}\right)$ & 21.10 & 3.09 \\
\hline $\mathrm{OD}\left(\mathrm{mg} \mathrm{L}^{-1}\right)$ & 7.40 & 7.47 \\
\hline
\end{tabular}

Comparing the sampled sites and periods of macroinvertebrate collection, the greatest diversity, equitability, richness, and number of individuals were recorded after dam construction. These results can be explained by the regularization of the river, which favored the fixation of the macroinvertebrate community downstream of the dam in the Poxim-Açu River. The abiotic changes that occurred in the Poxim-Açu River in the period before and after the construction of the dam can be seen in (Table 4), there was a reduction of the maximum flow values $\left(6.94 \mathrm{~m}^{3} \mathrm{~s}^{-1}\right.$ to $\left.4.71 \mathrm{~m}^{3} \mathrm{~s}^{-1}\right)$ and the average depth reduction $(0.46 \mathrm{~m}$ to $0.34 \mathrm{~m})$. Among the water quality alterations, the turbidity was reduced (43.1 NTU to $7.68 \mathrm{NTU}$ ), as well as the nitrate $\left(3.02 \mathrm{mg} \mathrm{L}^{-1}\right.$ para $\left.0.86 \mathrm{mg} \mathrm{L}^{-1}\right)$ and the chlorophyll $\left(21.01 \mu \mathrm{g} \mathrm{L}^{-1}\right.$ to $\left.0.86 \mu \mathrm{g} \mathrm{L}^{-1}\right)$.

Flow regularization contributes to increasing the availability and variety of habitats, increasing the composition of biotic communities (Callisto et al., 2011). Studies on macroinvertebrate communities after dam construction showed shifts in the structure, biodiversity, and richness of the communities, due to changes in the type of substrate, riverflow speed and water temperature upstream of the dams (Kjaerstad et al., 2018; Phillips et al., $2015 ; 2016)$. In addition, another study showed that the construction of dams cause an increase of biomass and a reduction of macroinvertebrate taxon richness at sites upstream of the dam (Wu et al., 2019).

Galdean et al. (2000) clarify that the study of the diversity of habitats offers an opportunity for a proper assessment of the levels of anthropic impacts on river basin sites, constituting an important tool for Environmental Monitoring Programs. For a better estimation of the 
Macroinvertebrate Biodiversity parameters, the Shannon-Wiener Diversity Index (H'), the Pielou Equitability Index (J'), the EPT Index (Ephemeroptera, Plecoptera and Trichoptera), the Total Richness (S), Total Number of Individuals (n) and the Dominance (k) for each sampling site and period were calculated (Table 5).

Table 5. Shannon-Wiener Diversity (H'), Pielou Equitability (J'), EPT; Total Richness(S), Number of Individuals (n) and Dominance (k) for each Sampling Site before and after Dam Construction.

\begin{tabular}{ccccccccc}
\hline & \multicolumn{8}{c}{ Periods of Data Collection } \\
\cline { 2 - 9 } Estimators & \multicolumn{7}{c}{ Before the Dam (2013) } & \multicolumn{5}{c}{ After the Dam (2015) } \\
\cline { 2 - 9 } & Point 1 & Point 2 & Point 3 & Mean & Point 1 & Point 2 & Point 3 & Mean \\
\hline H' & 1.90 & 1.95 & 1.68 & 1.84 & 2.39 & 2.37 & 2.53 & 2.43 \\
J' & 0.66 & 0.67 & 0.59 & 0.64 & 0.72 & 0.68 & 0.74 & 0.71 \\
S & 18.00 & 18.00 & 17.00 & 17.66 & 28.00 & 32.00 & 31.00 & 30.33 \\
N & 1581.00 & 1501.00 & 1684.00 & 1588.66 & 2758.00 & 2855.00 & 1983.00 & 2.532 .00 \\
K (\%) & 0.22 & 0.18 & 0.28 & 0.22 & 0.12 & 0.13 & 0.10 & 0.11 \\
EPT (\%) & 63.18 & 65.55 & 49.82 & 59.51 & 60.22 & 54.92 & 39.18 & 51.44 \\
BMWP & 93.00 & 93.00 & 102.00 & 96.00 & 147.00 & 155.00 & 164.00 & 155.33 \\
\hline
\end{tabular}

In this study, dam construction also affected the community structure of macroinvertebrates. The Coleoptera order increased in the number of individuals, from 16 $(0.33 \%)$ before the dam construction to 259 (3.4\%) after the dam construction. The Coleoptera species are known to be generalists, exploring a diversity of habitats, and are also very tolerant to pollutants. On the other hand, there was a decrease in the number of individuals of the Orders Hemiptera from 1007 (21.12\%) to 972 (12.79\%) and Diptera from $376(7.88 \%)$ to $172(2.26 \%)$. Among the orders sensitive to disturbances and pollution, there was a reduction in the number $(2,349-49.28 \%)$ of Ephemeroptera to $1,346(17.71 \%)$; however, the Orders Trichoptera 473 (9.92\%); 2,660 (35.01\%) and Odonata $528(11.07 \%) ; 2,142(28.19 \%)$ increased in many individuals and proportions.

In addition, Vallania and Corigliano (2007) showed that the distribution of macroinvertebrate functional feeding groups was also affected after dam construction, presenting an increase in the number of filter-feeding macroinvertebrates, scrapers, and predators and a decline in the number of collectors and shredders after dam construction.

In this study, 6.828 specimens of the Ephemeroptera and Trichoptera orders were collected (55.23\% of the total of individuals collected). The order Ephemeroptera was the most abundant in the number of individuals (3.695), distributed in 4 taxons, while the order Trichoptera was represented by 3.133 individuals distributed in 5 taxons.

Among aquatic insects, these orders play an important role as bioindicators of water quality, mainly due to their great abundance in the structure of benthic communities and due to their contribution to species' diversity (Callisto et al., 2001). Taking into consideration the EPT environmental quality index, the values obtained for Points 1 and 2 allow us to classify the water quality as "Good" for both periods, with values of 63.18 and 65.55 for the period before the dam and values of 60.22 and 54.22 after the construction of the dam, while Stretch 3 presents values that classify them as "Regular".

The BMWP index presented an average score of 155 after dam construction (Table 4), classifying the water quality as "Excellent" (Class 1; >150) (Alba-Tercedor, 1996) (Table 1). This result differed from that of Oliveira (2013), before dam construction, where the water quality was classified as "Good" (Class 2; BMWP=96; Table 1). The BMWP index is qualitative, and it considers only the presence or absence of families. The greater the Family score, the greater the Family sensitivity to anthropic impacts along the river, comparing 
different degrees of environmental integrity. Some families have an exceedingly small weight in the index, which is not representative, so they are not considered for the BMWP index analysis.

\section{CONCLUSION}

The construction of the Poxim-Açu River dam affected the composition and structure of the macroinvertebrate community. After the construction, there was an increase in diversity and species richness.

The BMWP index calculated after the dam construction indicated an improvement of water quality when comparing the two periods, probably because the damming of the river and the control of its flow favored the stabilization of the macrofauna, while the EPT index indicated no change in the quality of the water.

Further research is needed to determine the long-term impacts of dam construction on biodiversity of aquatic communities, especially with a focus on the migration routes dynamics, habitats fragmentation, shifts in the river-flow rates, temperature, water quality, sediments and substrates dynamics, food availability and on other physical-chemical parameters at sites upstream and downstream of the damming.

\section{REFERENCES}

ALBA-TERCEDOR, J. Macroinvertebrados acuáticos y calidad de las aguas de los ríos. In: SIAGA, 2., 1996, Almeria. Proceedings[...] Madrid: Instituto Tecnologico Geominero de España, 1996. p. 203-213.

BAPTISTA, D. F. Uso de macroinvertebrados em procedimentos de biomonitoramento em ecossistemas aquáticos. Oecologia Brasiliensis, v. 12, n. 3. p. 425- 441, 2008.

BISPO, P. C.; OLIVEIRA, L. G.; CRISC, V. C.; SILVA, M. M. A pluviosidade como fator de alteração da entomofauna bentônica (Ephemeroptera, Plecoptera e Trichoptera) em córregos do Planalto Central do Brasil. Acta Limnologica Brasiliensia, v. 13, n. 2, p. 19, 2001.

BROOKS, A. J.; WOLFENDEN, B.; DOWNES, B. J.; LANCASTER, J. Barriers to dispersal: The effect of a weir on stream insect drift. River Research and Applications, v. 34, n. 10, p. 1244-1253, 2018. https://doi.org/10.1002/rra.3377

CALLISTO, M.; MORETTI, M.; GOULART, M. Macroinvertebrados bentônicos como ferramenta para avaliar a saúde de riachos. Revista Brasileira de Recursos Hídricos, v. 6, n. 1, p. 71-82, 2001.

CALLISTO, M.; POMPEU, P. S.; TUPINAMBÁS, T. H.; CASTRO, D. M. P.; FRANÇA, J.; SANTOS, H. A. et al. Componentes bióticos para avaliações de vazões ecológicas a jusante de barramento hidrelétrico. In: SIMPÓSIO BRASILEIRO DE RECURSOS HÍDRICOS, 19., 2011, Maceió. Anais[...]. Porto Alegre: ABRH, 2011.

CAMARGO, P. R. da S.; SOUZA, F.; BURANELLO, P. A. de A. Influência de impactos antrópicos na comunidade de macroinvertebrados na bacia do baixo Rio Grande. Maringá (PR). Revista em Agronegócio e Meio Ambiente - RAMA, v. 12, n. 2, p. 643-662, 2019. https://doi.org/10.17765/2176-9168.2019v12n2p643-662 
COPATTI, C. E.; MOREIRA, T. B.; MENZEL, C. A. Environmental quality assessment of a micro basin in southern Brazil through different approaches. Ambiência, v. 10, n. 2, p. 511-526, 2014.

DYNESIUS, M.; NILSSON, C. Fragmentation and flow regulation of river systems in the northern third of the world. Science, v. 266, p. 753-762, 1994. https://doi.org/10.1126/science.266.5186.753

GALDEAN, N.; CALliSTO, M.; BARBOSA, F. A. R. Lotic Ecosystems of Serra do Cipó, southeast Brazil: water quality and a tentative classification based on the benthic macroinvertebrate community. Aquatic Ecosystem Health and Management, v. 3, p. 545-552, 2000. https://doi.org/10.1080/14634980008650691

GONÇALVES, F. B.; MENEZES, M. S. de. Análise comparativa de índices bióticos de avaliação de qualidade de água, utilizando macroinvertebrados, em um rio litorâneo do estado do Paraná, sul do Brasil. Biota Neotropica, v. 11, n. 4, p. 27-36, 2011. https://doi.org/10.1590/S1676-06032011000400002

HAMMER, Ø. PAleontological STatistics Version 3.15. Reference manual. Oslo: Natural History Museum. University of Oslo, 2017. p. 253.

HOLT, C. R.; PFITZER, D.; SCALLEY, C.; CALDWELL, B. A.; CAPECE, P. I.; BATZER, D. P. Longitudinal variation in macroinvertebrate assemblages below a large-scale hydroelectric dam. Hydrobiologia, v. 755, p. 13-26, 2015. https://doi.org/10.1007/s10750-015-2212-6

KJAERSTAD, G.; ARNEKLEIV, J. V.; SPEED, J. D. M.; HERLAND, A. K. Effects of hydropeaking on benthic invertebrate community composition in two central Norwegian rivers. River Research and Applications, v. 34, p. 218-231, 2018. https://doi.org/10.1002/rra.3241

KRAJENBRINK, H. J.; ACREMAN, M.; DUNBAR, M. J.; HANNAH, D. M.; LAIZÉ, C. L. R.; WOOD, P. J. Macroinvertebrates community responses to river impoundment at multiple spatial scales. Science of the Total Environment, v. 650, p. 2648-2656, 2019. https://doi.org/10.1016/j.scitotenv.2018.09.264

MAGNAI, R.; NESSIMIAN, J. L.; BAPTISTA, D. F. Manual de identificação de macroinvertebrados aquáticos do Estado do Rio de Janeiro: para atividade técnica de ensino e treinamento em programas de avaliação da qualidade ecológica dos ecossistemas lóticos. Rio de Janeiro: Technical Books, 2010.

MAYNARD, C. M.; LANE, S. N. Reservoir compensation releases: impact on the macroinvertebrate community of the derwent river, Northumberland, UK-A longitudinal study. River Research and Applications, v. 28, p. 692-702, 2012. https://doi.org/10.1002/rra.2557

OLIVEIRA, A. V. Sazonalidade e estrutura da comunidade de insetos aquáticos e qualidade ambiental em um trecho do rio Poxim Açu, São Cristóvão, Sergipe. 2013. 47p. Monografia (Técnico em Agroecologia) - Instituto Federal de Sergipe, Campus São Cristóvão, 2013.

PHILLIPS, I. D.; POLLOCK, M. S.; CHIVERS, D. P. Benthic communities through the construction of a major reservoir and 40 years of change. Fundamental and Applied Limnology, v. 188, p. 279-288, 2016. https://doi.org/10.1127/fal/2016/0906 
PHILLIPS, I. D.; POLLOCK, M. S.; BOWMAN, M. F.; and CHIVERS, D. P. Thermal alteration and macroinvertebrate response below a large northern great plains reservoir. Journal of Great Lakes Research, v. 41, p. 155-163, 2015. https://doi.org/10.1016/j.jglr.2015.07.005

POMPEU, P. S.; ALVES, C. B. M.; CALLISTO, M. The effects of urbanization on biodiversity and water quality in the Rio das Velhas basin, Brazil. American Fisheries Society Symposium, v. 47, p. 11-22, 2005.

ROCHA, R. M.; LUCAS, A. A. T.; ALMEIDA, C. A. P.; MENEZES NETO, E. L.; AGUIAR NETTO, A. O. Caracterização morfométrica da sub-bacia do rio Poxim Açú, Sergipe, Brasil. Revista Ambiente e Água, v. 9, n. 2, p. 276-287, 2014. https://doi.org/10.4136/ambi-agua.1289

TONKIN, J. D.; OLDEN, J. D.; MERRITT, D. M.; REYNOLDS, L. V.; LYTLE, D. A. Flow regime alteration degrades ecological networks in riparian ecosystems. Nature Ecology \& Evolution, v. 2, p. 86-93, 2018. https://doi.org/10.1038/s41559-017-0379-0

VALLANIA, A.; CORIGLIANO, M. Del C. The effect of regulation caused by a dam on the distribution of the functional feeding groups of the benthos in the sub basin of the Grande River (san Luis, Argentina). Environmental Monitoring and Assessment, v. 124, n. 13, p. 201-209, 2007. https://doi.org/10.1007/s10661-006-9218-5

WANG, J.; DING, L. Y.; TAO, J.; DING, C. Z.; HE, D. M. The effects of dams on macroinvertebrates: global trends and insights. River Research and Applications, v. 35, p. 1-12, 2019. https://doi.org/10.1002/rra.3431

WHITE, J. C.; HANNAH, D. M.; HOUSE, A.; BEATSON, S. J. V.; MARTIN, A.; WOOD, P. J. Macroinvertebrate responses to flow and stream temperature variability across regulated and non-regulated rivers. Ecohydrology, v. 10, n. 1, p. 1-21, 2017. https://doi.org/10.1002/eco.1773

WU, H.; CHEN, J.; XU, J.; ZENG, G.; SANG, L.; LIU, Q. Effects of dam construction on biodiversity: a review. Journal of Cleaner Production, v. 221, p. 480-489, 2019. https://doi.org/10.1016/j.jclepro.2019.03.001 